\title{
When consumers touch: a conceptual model of consumer haptic perception \\ Consumer \\ haptic \\ perception
}

\author{
Achini Tharaka Ranaweera
}

\author{
University of Moratuwa, Moratuwa, Sri Lanka
}

Received 11 August 2021 Accepted 7 October 2021

\begin{abstract}
Purpose - Touch plays an important role in the evaluations of products. However, prior quantitative touch research does not present a holistic perspective of haptics. This study aims to provide a more comprehensive understanding of haptic information that consumers attain from touch.

Design/methodology/approach - Adopting a qualitative research approach, semi-structured, depth interviews were conducted with industry experts.

Findings - Based on the findings, this research proposes a conceptual model of consumer haptic perception consisting of seven key influences, namely, the effects of haptic sensation, haptic perception, the influence of individual factors, the influence of external environmental factors, the multi-dimensionality of haptics, haptic cue congruity and haptic dominance.

Practical implications - This study suggests firms to understand the importance of consumers' haptic perception as an opportunity to engage an individual's heart and mind through information attained through touch.

Originality/value - This is the first study in marketing to propose a conceptual model of haptics comprising several new haptic influences. This model contributes to the emerging literature of sensory marketing by providing directions for future touch research by capturing the dynamic nature of haptics.
\end{abstract}

Keywords Sensory marketing, Touch, Haptics, Consumer haptic perception

Paper type Research paper

\section{Cuando los consumidores tocan: Un modelo conceptual de la percepción táctil del consumidor}

\section{Resumen}

Objetivo - El tacto desempeña un papel importante en nuestras evaluaciones de los productos. Sin embargo, las investigaciones cuantitativas anteriores sobre el tacto no presentan una perspectiva holística de la percepción táctil. Este artículo pretende ofrecer una comprensión más completa de la información táctil que los consumidores obtienen del contacto.

(C) Achini Tharaka Ranaweera. Published in Spanish Journal of Marketing - ESIC. Published by Emerald Publishing Limited. This article is published under the Creative Commons Attribution (CC BY 4.0) licence. Anyone may reproduce, distribute, translate and create derivative works of this article (for both commercial and non-commercial purposes), subject to full attribution to the original publication and authors. The full terms of this licence maybe seen at http://creativecommons.org/ licences/by/4.0/legalcode

The first author gratefully acknowledges Professor Brett Martin and Associate Professor HS Jin from Queensland University of Technology (QUT) for their supervision and the financial and administrative support from QUT during the completion of this research.

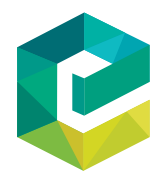

Spanish Journal of Marketing Vol. 26 No. 1, 2022 pp. $23-43$ Emerald Publishing Limited
2444-9709 DOI 10.1108/SJME-08-2021-0152 
SJME

26,1

Metodología - Adoptando un enfoque de investigación cualitativa, se realizaron entrevistas semiestructuradas en profundidad con expertos del sector.

Resultados - A partir de los resultados, esta investigación propone un modelo conceptual de la percepción táctil del consumidor que consta de siete influencias clave: Los efectos de la sensación háptica, la percepción háptica, la influencia de los factores individuales, la influencia de los factores ambientales externos, la multidimensionalidad de la sensación táctil, la congruencia de las pistas táctiles y la dominancia de la sensación táctil.

Implicaciones prácticas - Este estudio sugiere a las empresas que comprendan la importancia de la percepción táctil de los consumidores como una oportunidad para captar el corazón y la mente del individuo a través de la información obtenida mediante el tacto.

Originalidad - Este es el primer estudio en marketing que propone un modelo conceptual de la percepción táctil que incluye varias influencias táctiles nuevas. Este modelo contribuye a la literatura emergente del marketing sensorial proporcionando direcciones para la futura investigación táctil al capturar la naturaleza dinámica del sentido del tacto.

Palabras clave - Marketing sensorial, Tacto, Háptica, Percepción háptica del consumidor

Tipo de artículo - Trabajo de investigación

\section{当消费者触摸时：消费者触觉感知的概念模型}

\section{摘要}

目的 - 触摸在我们对产品的评价中起着重要作用。然而, 在先前定量的触觉研究中并未呈现触觉的 整体视角。本文旨在更全面地了解消费者通过触摸获得的触觉信息。

方法 - 本文采用定性研究方法, 与行业专家进行了牛结构化的深度访谈。

㸴究结果 - 本硎究提出了一个消费者触觉感知的概念模型, 其中包括七个关键影响因素: 触觉的影 响、触觉感知、个人因素的影响、外部环境因素的影响、触觉的多维性、触觉线索的一致性和触觉 的主导性。

实际意义 - 这项㸴究建议企业了解消费者触觉感知的重要性, 并将触觉信息传达作为吸引消费者心 灵的机会。

原创性 - 这是营销领域首次提出触觉概念模型的硎究, 该模型包含几种新的触觉影响因素。这个触 觉概念模型通过捕捉触觉的动态特性为未来的触觉研究提供方向, 从而为新兴的感官营销文献做出了 贡献。

关键词：感官营销, 触摸, 触觉, 消费者触觉感知

文章类型：砶究型论文

\section{Introduction}

Touch is a fundamental human sense which plays a significant role in marketing and consumer behaviour (Jha et al., 2020; Krishna, 2010). For consumers, touch is used by people to engage with and to understand products through haptic information (Jha et al., 2020; Lederman and Klatzky, 1993; Peck and Childers, 2003b; Ranaweera et al., 2021). However, much of the prior research has adopted a narrow perspective, treating haptics as a single independent variable that affects other marketing constructs (Krishna et al., 2010; Krishna and Morrin, 2008; Peck and Johnson, 2011; Peck and Wiggins, 2006; Ringler et al., 2019). For example, a stream of research in marketing has examined person-based individual differences in the need for touch (Citrin et al., 2003; Grohmann et al., 2007; Peck and Childers, 2003a; Ringler et al., 2019; Webb and Peck, 2015).

When we consider how consumers can use touch-based information to evaluate a product (e.g. by touching, feeling or weighing them), there appears to be a need to provide researchers with a more holistic view of how consumers use haptics. Surprisingly, no prior marketing research has gained a broader understanding of the dynamic nature of haptics. To address this knowledge gap in the literature, this current research adopts inductive 
reasoning to explore the nature of haptics and what constitutes haptics, thereby proposing a conceptual model of consumer's haptic perception. Thus, the following research questions were set:

$R Q 1$. What are the key types of haptic properties of products?

$R Q 2$. How are these haptic properties related to the four material properties: texture, weight, temperature and hardness?

Consumer haptic perception

This is the first study in touch literature which aims to develop a conceptual framework of consumer haptic perception. Principles of embodied cognition (Wilson, 2002) and the conceptual framework of sensory marketing (Krishna, 2012) provided the theoretical support to develop this conceptual model. Identification of such a model will contribute to the emerging literature of sensory marketing by providing directions for future touch research by capturing the dynamic nature of haptics and may help marketers refine their sensory marketing strategies. To fulfil this research aim, a semi-structured, depth interviews were conducted with industry experts as an effective means of qualitative data collection.

This paper first presents a conceptual background on sensory marketing. Secondly, it reviews the important role of haptics in marketing. The next section presents the method used in this research followed by the research findings. We conclude with a discussion of the theoretical and practical implications of our findings and avenues for future research.

\section{Literature review}

\subsection{Marketing to senses}

Humans perceive the world around them through their senses. Sensory marketing incorporates the five human senses, namely, sight, sound, smell, taste and touch into key marketing decisions (Hultén, 2015; Krishna, 2010; Krishna et al., 2017; Krishna et al., 2016). Embracing the theoretical perspective of embodied cognition, which posits that human cognitive processes are deeply rooted in the body's interactions with the world (Krishna and Schwarz, 2014; Wilson, 2002), sensory marketing suggests marketers to engage consumer's senses which affects their perception, judgement and behaviour (Krishna et al., 2016).

Touch is the first sense to develop in the human sensory system (Gallace and Spence, 2011) and the last sense we lose with age (Krishna, 2012). Touch is a means of direct experience with a product (Krishna, 2010; Ranaweera et al., 2021). Touch sense is linked to information and feelings about a product through both physical and psychological interactions (Peck and Childers, 2003a). The product (Peck and Childers, 2003b; Pino et al., 2020; Ranaweera et al., 2021; Velasco and Spence, 2019) the individual (Flavián et al., 2017; Kühn et al., 2020; Peck and Childers, 2003a; Peck and Childers, 2006; Ringler et al., 2019) and the environment (Jha et al., 2020; Peck and Childers, 2006) are the three drivers of a consumer's motivation to touch. Although sensory researchers have recognised the importance of touch in consumption, their attention so far has been largely on the personal factors or the individual differences in the need for touch. To date, researchers have overlooked the role product differences of touch plays in marketing. This is especially important because products differ in their haptic information which significantly impact on the functional and aesthetic performance goals of a product design, consequently influence consumers' psychological and behaviour responses (Batra et al., 2016; Velasco and Spence, 2019). 
SJME

26,1

\subsection{Haptics}

Haptics has its origins in psychophysics and perception literature. The word haptics derives from a Greek term meaning "able to lay hold of" (Gibson, 1966, p. 97). Haptics is referred as "the functionally discrete system involved in the seeking and extraction of information by the hand" (Gibson, 1966). The haptic system has its own unique pathways for encoding objects and that ease of encoding is a strong influence on the salience of object attributes (Klatzky et al., 1987).

Haptic information attained from the sense of touch is vital for evaluating products that differ in terms of four primary material properties that correspond to texture, weight, temperature and hardness (Lederman and Klatzky, 1993b; Peck and Childers, 2003b). Prior literature suggests that these four material properties of products are the most accessible to our sense of touch (Klatzky and Lederman, 1993; Klatzky and Peck, 2012). Properties can be described at different levels of specificity, such as roughness or warmness (Klatzky and Lederman, 1993; Klatzky and Peck, 2012). These material properties serve to differentiate objects at a more specific degree of categorisation, whereas geometric information such as size and shape help people to easily recognise objects at a more basic level of categorisation (Klatzky and Lederman, 1993; Klatzky and Peck, 2012). For example, a consumer can more easily evaluate a sweater's texture and weight by touching the surface of the material and holding the garment than by visually inspecting it. Klatzky and Lederman (2003) explain that certain haptic properties are more diagnostic than others, for example, surface smoothness is often associated with infant clothing. This is important because consumers can be motivated to touch a product before purchase, when the product's material property is relevant to its utility and where they are more prone to touch if a product differs from other products in a diagnostic manner on the four material properties (Peck and Childers, 2003a).

\subsection{The role of haptics in marketing}

Haptics in marketing refers to the "active seeking and perception by the hands" (Krishna, 2010). Many brands with physical products seek to create a positive haptic experience for consumers or allow them to gain information to encourage purchase through the sense of touch. For instance, Apple facilitates their customer's haptic interactions with products in their retail stores (Solomon et al., 2013). Similarly, Swedish home furniture retailer IKEA enables its customers to touch and interact with their products (Hultén, 2015). Britain's Asquith and Dairies (ASDA) removed the wrapping from several toilet tissue brands to encourage shoppers to touch, feel and compare textures which boosted sales for their own in-store brand (Solomon et al., 2013).

Prior studies that have examined the influence of product-based haptic information on consumer behaviour reveal some important findings (De Canio and Fuentes-Blasco, 2021; Jha et al., 2020; Ranaweera et al., 2021). For example, Ranaweera et al. (2021) found in a series of experiments that a consumer's touch-based information can influence what the perceived personality of the product. For example, a smooth product texture and heavy weight was related to brands being perceived as exciting. There is a perceptual transfer of haptic information from a package or a container to the judgement of the product (Velasco and Spence, 2019). For example, the firmness of the cup in which the water is served influences consumer judgements of the water. Specifically, the water tasted better when drunk from a firm cup than a flimsy cup (Krishna and Morrin, 2008).

Moreover, prior literature suggests that haptic inputs from a product container held in a consumer's hand impact food perceptions and preferences. For example, the surface texture of food containers (tough/grainy versus smooth) affects the perception of the food we eat 
(Piqueras-Fiszman and Spence, 2012). Further, haptic information surrounding customers while they are shopping can influence their shopping behaviour (Jha et al., 2020; Ringler et al., 2019). For instance, heavy and soft haptic cues in a retail or service environment impact purchase behaviour (Jha et al., 2020).

As discussed, haptics influence consumer perception of products, packaging and physical surroundings. Therefore, it is important that we capture the dynamism of haptics as a key driver of successful marketing. Thus, the following research questions were set:

- What are the key types of haptic properties of products?

- How are these haptic properties related to the four material properties, namely, texture, weight, temperature and hardness?

\section{Methodology}

Product-based salience of haptic information is clearly an understudied phenomenon within the evolving touch literature. Given the background, this is one of the first marketing research studies to explore the dynamic nature of haptics. Thus, a qualitative approach was deemed appropriate. Indeed, qualitative research gives insights on unexplored topics (Babbie, 2017; Hennink et al., 2020) and can be used to distinguish subtle aspects of phenomena that researchers cannot otherwise capture (Creswell, 2003). This research decision was further supported by two prior sensory marketing studies (Littel and Orth, 2013; Orth and Malkewitz, 2008).

\subsection{Depth interviews}

This research adopted depth interviews with industry experts. Interviews allow researchers to refine the questions and ask extra questions to confirm the sufficiency of the exploration (Creswell, 2003; Saunders et al., 2018). Talking to experts can be "crystallisation points" for practical insider knowledge (Bogner et al., 2009).

To determine the research context, a consumer free recall task was conducted following (Grohmann et al., 2007; Peck, 1999). A convenience sample of students (45) were recruited from a large public university in Australia. Participants were asked to list any products which they evaluate with touch before buying, resulting in a list of 14 product categories. Among them, clothing was named first by a total of 40 of the 45 participants and this was listed first by a total of 30 participants. Categories for which touch is important included in descending order: clothing, accessories, products, consumer electronics, furniture, home wear, cosmetics and beauty products, office, household and kitchen appliances, automobiles, toys and kids' items, plants, sports equipment and music instrument. This showed the significance of touching clothing as a product category. Thus, fashion and textile as the industry sector was selected to explore the nature of haptics.

Next, adopting a judgement sampling strategy, a set of Australian fashion industry experts such as fashion designers, textile technologists who possess expert knowledge with 10 to 20 years and experience with international clients were approached. Monooperation bias in the interviews were avoided by selecting experts from various organisations, education background and importantly from various professional careers (Shadish et al., 2002) (Table 1). The sample size is based on the completeness of the information obtained from analysis of the transcripts, with interview quality and participant diversity in the included sample being considered more important than the absolute number of interviews (Kerr et al., 2010). The sample size was not 


\begin{tabular}{|c|c|c|c|c|c|}
\hline & & & & & \\
\hline 26,1 & $\begin{array}{l}\text { Informants } \\
\text { ID }\end{array}$ & Job description of the informants & $\begin{array}{l}\text { Industry } \\
\text { experience }\end{array}$ & Education & Time/date \\
\hline & i1 & Fashion designer and a senior lecturer & 10 years & $\begin{array}{l}\text { Doctor of } \\
\text { philosophy }\end{array}$ & $\begin{array}{l}22 / 09 / 2016- \\
10.00-11.30 \text { a.m. }\end{array}$ \\
\hline & i2 & $\begin{array}{l}\text { Fashion designer, skilled pattern maker and } \\
\text { a lecturer }\end{array}$ & 25 years & Master's degree & $\begin{array}{l}04 / 09 / 2017- \\
3.00-4.30 \text { p.m. }\end{array}$ \\
\hline 8 & i3 & Fashion studio technician & 10 years & $\begin{array}{l}\text { Bachelor's } \\
\text { degree }\end{array}$ & $\begin{array}{l}\text { 03/11/2017 - } \\
\text { 8-10 a.m. }\end{array}$ \\
\hline & i4 & Fashion development manager & 16 years & $\begin{array}{l}\text { Bachelor's } \\
\text { degree }\end{array}$ & 07/09/2017- \\
\hline & i5 & $\begin{array}{l}\text { Fashion designer, pattern maker, wholesale } \\
\text { fabric agent, former design and a production } \\
\text { manager }\end{array}$ & 30 years & Diploma & $\begin{array}{l}\text { 20/09/2017 - } \\
\text { 3.15-4.30 p.m. }\end{array}$ \\
\hline & i6 & Fashion designer & 25 years & $\begin{array}{l}\text { Doctor of } \\
\text { philosophy }\end{array}$ & $\begin{array}{l}01 / 09 / 2017- \\
8.00-10.00 \text { a.m. }\end{array}$ \\
\hline & i7 & Textile technologist & 20 years & $\begin{array}{l}\text { Bachelor's } \\
\text { degree }\end{array}$ & $\begin{array}{l}\text { 20/09/2017 - } \\
6.00-7.00 \text { p.m. }\end{array}$ \\
\hline & i8 & High end fashion designer & 30 years & $\begin{array}{l}\text { Bachelor's } \\
\text { degree }\end{array}$ & $\begin{array}{l}\text { 06/09/2017- } \\
8.30-10 \text { a.m. }\end{array}$ \\
\hline & i9 & Bridal couture designer & 20 years & High school & $\begin{array}{l}\text { 19/09/2017- } \\
\text { 8.00-10.00 a.m. }\end{array}$ \\
\hline & i10 & $\begin{array}{l}\text { High end fashion designer and a past design } \\
\text { manager }\end{array}$ & 15 years & Master's degree & $\begin{array}{l}\text { 17/09/2017 - } \\
4.00-5.00 \text { p.m. }\end{array}$ \\
\hline & i11 & $\begin{array}{l}\text { Associate lecturer, sourcing and purchasing } \\
\text { support officer, business and brand } \\
\text { development manager, } \\
\text { creative director and designer }\end{array}$ & 10 years & $\begin{array}{l}\text { Professional } \\
\text { doctorate }\end{array}$ & $\begin{array}{l}\text { 01/10/2017 - } \\
8.30-10.00 \text { a.m. }\end{array}$ \\
\hline & $\mathrm{i} 12$ & $\begin{array}{l}\text { Associate lecturer, costume maker and a } \\
\text { designer }\end{array}$ & 8 years & $\begin{array}{l}\text { Bachelor's } \\
\text { degree }\end{array}$ & $\begin{array}{l}04 / 10 / 2018- \\
8.30-10.00 \text { a.m. }\end{array}$ \\
\hline & i13 & $\begin{array}{l}\text { Textile engineer, consultant for start-ups, } \\
\text { past: open innovation entrepreneur }\end{array}$ & 9 years & $\begin{array}{l}\text { Doctor of } \\
\text { philosophy } \\
\text { (reading) }\end{array}$ & $\begin{array}{l}\text { 06/10/2018 - } \\
8.00-10.00 \text { a.m. }\end{array}$ \\
\hline $\begin{array}{l}\text { Table } 1 . \\
\text { Characteristics of } \\
\text { informants }\end{array}$ & i14 & Fashion designer and a lecturer & 10 years & $\begin{array}{l}\text { Doctor of } \\
\text { philosophy } \\
\text { (reading) }\end{array}$ & $\begin{array}{l}\text { 08/10/2018 - } \\
9.00-11.00 \text { a.m. }\end{array}$ \\
\hline
\end{tabular}

determined a priori. Instead, informants were interviewed until data saturation was achieved.

The majority of interviews were conducted face-to-face inside the informant's workplace: offices, retail stores or design houses/boutiques. This allowed informants to use real products and materials to elaborate on discussion points. Verbatim transcripts from audiotaped interviews served as the primary texts for interpretation. All interview transcripts were electronically coded using NVivo 11, which assisted the researcher to store, organise, manage and reconfigure the data more efficiently than manual coding.

\subsection{Development of the interview guide}

To develop the semi-structured interview guide, an in-depth literature search was conducted. This study identified key types of haptic properties corresponding to four material properties of products, namely, texture, weight, temperature and hardness. Following Nolan and Garavan (2016), the literature search strategy included subject area, 
keywords and search terms, information search techniques, databases and search engines and respective academic journals (Table 2). The parameters of the literature review are indexed journals published in the past 50 years in English language from North American and Europe. Haptics has its original roots in psychophysics and psychology literature. Therefore, the literature review began with those fields. The early experimental psychology studies theorised the phenomenological aspects of touch, subsequently extend to more empirically-based examinations of touch, such as identification of objects by touch (Klatzky and Lederman, 1992; Klatzky et al., 1985; Lederman and Klatzky, 2009); haptic exploration of objects and hand movements (Klatzky et al., 1993; Lederman and Klatzky, 1987; Wu et al., 2011); object properties that invite touch (Klatzky and Peck, 2012) and identification of materials by touch (Heller, 1989; Katz and Krueger, 1989). The literature review next

\begin{tabular}{|c|c|c|c|c|c|}
\hline Subject area & $\begin{array}{l}\text { Keywords and } \\
\text { search terms }\end{array}$ & $\begin{array}{l}\text { Search } \\
\text { techniques }\end{array}$ & $\begin{array}{l}\text { Databases and search } \\
\text { engines }\end{array}$ & Journal count and name & \\
\hline $\begin{array}{l}\text { Perception and } \\
\text { psychophysics }\end{array}$ & $\begin{array}{l}\text { Haptic } \\
\text { perception } \\
\text { Tactual } \\
\text { perception } \\
\text { Material } \\
\text { properties }\end{array}$ & $\begin{array}{l}\text { Boolean } \\
\text { Truncation } \\
\text { Phrase and } \\
\text { proximity } \\
\text { searching }\end{array}$ & $\begin{array}{l}\text { PsycINFO } \\
\text { Science direct }\end{array}$ & $\begin{array}{l}\text { 7-Acta Psychol } \\
\text { 6-Percept Psychophys } \\
\text { 4-Jexp psychol } \\
\text { 2-Science } \\
\text { 2-Atten Percept Psychophys } \\
\text { 2-IEEE Trans Haptics } \\
\text { 2-Perception } \\
\text { 2-Exp Brain Res } \\
\text { 1-Infant Behav Dev } \\
\text { 1-Jpn Psychol Res } \\
\text { 1-J Genet Psychol } \\
\text { 1-Neurosci. Lett. } \\
\text { 1-Child Dev } \\
\text { 1-Sci Educ } \\
\text { 1-WIREs Cogn Sci } \\
\text { 1-Can J Exp Psychol } \\
\text { 1-Brain Res. Bull } \\
\text { 1-Multi-sens Res. } \\
\text { 1-Philos Psychol. }\end{array}$ & \\
\hline $\begin{array}{l}\text { Marketing and } \\
\text { consumer } \\
\text { behaviour }\end{array}$ & $\begin{array}{l}\text { Sensory } \\
\text { marketing } \\
\text { Sensory touch } \\
\text { Haptics } \\
\text { Tactile } \\
\text { perception }\end{array}$ & $\begin{array}{l}\text { Boolean } \\
\text { Truncation } \\
\text { Phrase and } \\
\text { proximity } \\
\text { searching }\end{array}$ & $\begin{array}{l}\text { ABI/INFORM complete } \\
\text { (via ProQuest) } \\
\text { Emerging market case } \\
\text { studies (via Emerald) } \\
\text { Taylor and Francis }\end{array}$ & $\begin{array}{l}\text { 5-J. Consum. Res.. } \\
\text { 4-J. Consum. Psychol. } \\
\text { 3-Psychol Mark. } \\
\text { 2-J Mark. } \\
\text { 2-J. Retail. } \\
\text { 2-J. Prod. Brand. Manag. } \\
\text { 1-J Consum Mark. } \\
\text { 1-J Bus Res. } \\
\text { 1-Eur. J. Mark. }\end{array}$ & \\
\hline Product design & $\begin{array}{l}\text { Touch } \\
\text { Product design } \\
\text { Haptic } \\
\text { experience } \\
\text { Haptic design } \\
\text { Tactile design }\end{array}$ & $\begin{array}{l}\text { Boolean } \\
\text { Truncation } \\
\text { Phrase and } \\
\text { proximity } \\
\text { searching }\end{array}$ & $\begin{array}{l}\text { Design and applied } \\
\text { arts index (DAAI) (via } \\
\text { ProQuest) }\end{array}$ & $\begin{array}{l}\text { 4-Text. Res. J. } \\
\text { 2-Text.:J.Cloth Cult. } \\
\text { 1-Des. Issues. } \\
\text { 1-Int. J. Des. } \\
\text { 1-J.Des. Res. } \\
\text { 1-Des. } \\
\text { 1-J. Text. Inst. } \\
\text { 1-Psychol Aesthet Creat Arts } \\
\text { 1-Int J des Nat Ecodyn } \\
\text { 73 }\end{array}$ & $\begin{array}{r}\text { Table } 2 . \\
\text { Literature search }\end{array}$ \\
\hline Total & & & & 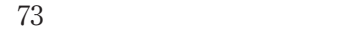 & strategy \\
\hline
\end{tabular}


SJME

26,1

30

determined research papers focussed on sensory touch published in top marketing and consumer behaviour journals. The literature of product design too was explored because of their growing interest in the implications of haptic experience for product design. The literature review resulted in an initial master list of over 200 references to haptics from 73 research papers. Repeatedly occurring similar haptic items were considered as a saturation point. If a paper contained haptic properties that were already identified, that article was taken out from the final analysis. Some items were eliminated based on a priori criteria, namely, lack of clarity, ambiguity, undesirable similarity to other items and questionable relevance.

The final haptic list of 45 haptic pairs of the most frequently used terms to represent four material properties with all redundant items eliminated. It consisted of both bipolar (e.g.: warm-cold) and unipolar adjectives (e.g.: stiff-not stiff). The individual lines represent points along the continuum defined by the respective adjectives. The identified haptic list sets the foundation of the semi-structured interview guide (Table 3).

\subsection{The coding process}

This research adopted two types of coding, namely, the first cycle of coding and the second cycle of coding (Saldaña, 2015). In the first cycle of coding, an open-ended initial coding approach was used aiming to remain open to all potential theoretical directions indicated by the reading of the data. This process generated 49 codes, which were carefully recoded and then categorised according to their relationships during the second cycle in which an axial coding approach was used. This process generated 17 codes. The coding process followed the format suggested by Gioia et al. (2013) (Table 4). In this process, some initial codes were merged together because of their frequency, inter-relationship and conceptual similarity. Finally, all second cycle codes were collated into seven potential themes, consequently, clear names for each theme were given. Next, vivid, compelling examples which capture the essence of themes to present with the final analysis were chosen. Following Saunders et al. (2018), the inductive thematic saturation approach was used and the saturation was confined to the level of analysis, thus the principal focus in the research

Based on your knowledge and experience being a fashion industry professional, please classify following haptic properties under the most suitable material property: texture, hardness, weight and temperature. E.g.

Warm-cool $=$ "Temperature" or N/A, if it does not apply in the fashion context

\begin{tabular}{lll}
\hline 1. Warm-cool & 16. Even-uneven & 31. Rugged-smooth \\
2. Hard-soft & 17. Solid-powdery & 32. Steady-loose \\
3. Firm-flimsy & 18. Bulky-light & 33. Fluffy-rough \\
4. Strong-weak & 19. Flexible-inflexible & 34. Spongy-solid \\
5. Stability-instability & 20. Flat-bumpy & 35. Itchy-not itchy \\
6. Rigid-malleable & 21. Structured-unstructured & 36. Feathery-not feathery \\
7. Stiff-not stiff & 22. Rounded-pointed & 37. Embossed-not embossed \\
8. Sharp-dull & 23. Relief-no relief & 38. Multi-layered-single-layered \\
9. Rough-smooth & 24. Substantial-empty & 39. Chalky-smooth \\
10. Rough-sleek & 25. Elastic-inelastic & 40. Silky-not silky \\
11. Wet-dry & 26. Sticky-slippery & 41. Fuzzy/hairy/furry-not fuzzy \\
12. Oily-dry & 27. Coated-uncoated & 42. Jagged-smooth \\
13. Heavy-light & 28. Waxed-un-waxed & 43. Viscous-watery \\
14. Compressible-non compressible & 29. Grainy/gritty-fine & 44. Brittle-unbreakable \\
15. Thick-thin & 30. Ribbed-not ribbed & 45. Coarseness-delicacy \\
& &
\end{tabular}

Table 3.

Semi-structured interview guide
16. Even-uneven

Sovid-powdery

19. Flexible-inflexible

20. Flat-bumpy

22. Rounded-pointed

23. Relief-no relief

24. Substantial-empty

27. Coated-uncoated

28. Waxed-un-waxed

9. Grainy/gritty-fine

30. Ribbed-not ribbed
31. Rugged-smooth

32. Steady-loose

33. Fluffy-rough

34. Spongy-solid

35. Itchy-not itchy

36 . Feathery-not feathery

37. Embossed-not embossed

38. Multi-layered-single-layered

41. Fuzzy/hairy/furry-not fuzzy

42. Jagged-smooth

43. Viscous-watery

. Brittle-unbreakable

45. Coarseness-delicacy 


\begin{tabular}{|c|c|c|}
\hline $\begin{array}{l}\text { Aggregate } \\
\text { dimensions }\end{array}$ & Second-order themes & First-order concepts \\
\hline $\begin{array}{l}\text { The effect of } \\
\text { haptic sensation }\end{array}$ & $\begin{array}{l}\text { The physical feeling that } \\
\text { results through touching }\end{array}$ & $\begin{array}{l}\text { Physical feeling; emotional connection; key driver of } \\
\text { retailing; reinforce design development process; relative } \\
\text { and arbitrary }\end{array}$ \\
\hline \multirow[t]{8}{*}{ Haptic perception } & Aesthetic appeal & $\begin{array}{l}\text { Design-related concerns; product category specific; } \\
\text { product type; current trend and market demand; drape } \\
\text { and handle }\end{array}$ \\
\hline & Perceived quality & $\begin{array}{l}\text { Product quality; functionality or performance-related; } \\
\text { reliability concerns; durability, transportability }\end{array}$ \\
\hline & Personality perception & $\begin{array}{l}\text { Relationship between haptics and person's personality; } \\
\text { femininity; social status; self-Image }\end{array}$ \\
\hline & Perceived comfort & Touch to evaluate the comfort of products \\
\hline & Perceived price & Haptics as a driver of the price of products \\
\hline & Luxury perception & Haptics evoke a perception of luxury \\
\hline & Perceived confidence & Sense of achievement; stability; feeling secure \\
\hline & Disgust & Negative consequences of product touch \\
\hline \multirow[t]{3}{*}{ Individual factors } & $\begin{array}{l}\text { Utilitarian-orientation of } \\
\text { touch }\end{array}$ & $\begin{array}{l}\text { Impact purchase decisions; touch as a compensation } \\
\text { mechanism; prior knowledge }\end{array}$ \\
\hline & $\begin{array}{l}\text { Hedonic-orientation of } \\
\text { touch }\end{array}$ & $\begin{array}{l}\text { Experience seeking; enjoy the feel and the sensation } \\
\text { from touching; online vs offline shopping preferences }\end{array}$ \\
\hline & Desire for unique haptics & Need for uniqueness; consciousness \\
\hline \multirow{2}{*}{$\begin{array}{l}\text { External } \\
\text { environmental } \\
\text { factors }\end{array}$} & Ambient temperature & $\begin{array}{l}\text { Ambient temperature-related; cold/hot weather } \\
\text { conditions; context specific }\end{array}$ \\
\hline & $\begin{array}{l}\text { Technological } \\
\text { advancements }\end{array}$ & New product developments and innovations \\
\hline $\begin{array}{l}\text { The multi- } \\
\text { dimensionality of } \\
\text { haptics }\end{array}$ & $\begin{array}{l}\text { Integration of several haptic } \\
\text { inputs }\end{array}$ & $\begin{array}{l}\text { Touch is multi-sensory; touch and other sensory } \\
\text { interactions }\end{array}$ \\
\hline $\begin{array}{l}\text { Haptic cue } \\
\text { congruity }\end{array}$ & $\begin{array}{l}\text { Haptic cue congruence/ } \\
\text { haptic cue incongruence }\end{array}$ & Semantic association; fit/unfit \\
\hline Haptic dominance & $\begin{array}{l}\text { Dominance effects among } \\
\text { the four material properties }\end{array}$ & $\begin{array}{l}\text { Most important haptics; commonly used haptics; } \\
\text { texture; weight; hardness; temperature }\end{array}$ \\
\hline
\end{tabular}

process lies in the analysis. Accordingly, the study reached theoretical saturation at the point when mounting instances of the same codes but no new codes occurred in the data.

\section{Findings}

This research identified seven data-driven influences, namely, the effects of haptic sensation, haptic perception, the influence of individual factors on haptic perception, the influence of external environmental factors on haptic perception, the multi-dimensionality of haptics, haptic cue congruity and haptic dominance. They are all conceptually related and can be depicted as a visual model as in Figure 1. Principles of embodied cognition (Wilson, 2002) and the conceptual framework of sensory marketing (Krishna, 2012) provided the theoretical support to develop this conceptual model.

\subsection{The effects of haptic sensation}

This research defines haptic sensation as "the sensation that results through touching and obtaining haptic information" (Krishna, 2012). As expressed by the informants, how things "feel" has extensive psychological implications beyond simply being good or bad. "Seduce", 


\section{SJME}

26,1

32

Figure 1.

Conceptual model: consumer's haptic perception

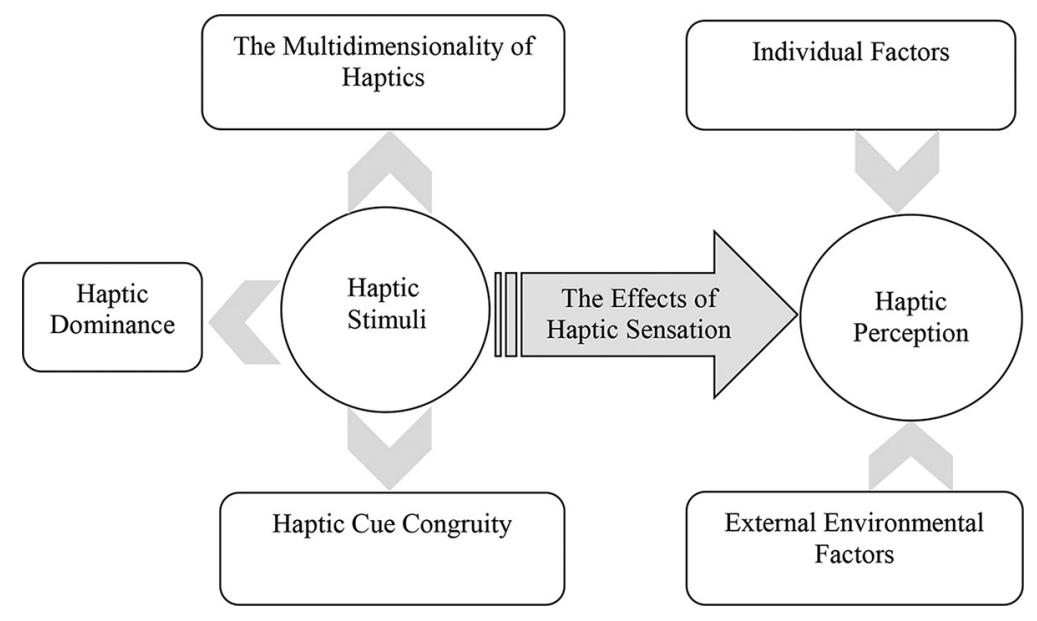

"impress", "influence", "love", "nice", "like" and "connection" were some of the adjectives informants used to describe the haptic sensations their customers felt. Data supported the assumption that the sense of touch is linked to information and feelings about a product, not only through mere physical interaction, but through powerful psychological interaction (Krishna, 2012; Peck and Childers, 2003b; Ranaweera et al., 2021). For example, Informant 5 observed:

Ultimately, they could be seduced if you like, by touching the actual fabric themselves. It could be the weight and feel of it. They would be quite impressed with the weight of the dress, but again I think that would influence their opinion of it(I 5).

Informant 12 drew on her experience as a luxury clothing retailer to stress how the physical connection a consumer builds with a product could lead to a strong emotional connection with it, which ultimately would go a long way towards persuading consumers to buy the product:

I worked in luxury retailing before and one of the things I discovered during that period was that if you can get someone into a changing room with a garment, they will be ten times more likely to purchase that. This is because once they actually make a physical connection with it by putting it on their body and seeing how it works and feels when it's on them, they actually make an emotional connection with it (I 12).

Moreover, informants suggested that the correct interpretation of the exact haptic sensation their customers felt played a vital role in successful retailing. For example, Informant 1 explained how this sensation could reinforce a successful design development process:

Haptics? Oh, that is enormously important. It is all about getting the most from the feel and the handle of the material by applying the right design to it. Every fabric has a unique feel, and so it must be incorporated into a design that will bring out the material's best qualities. The form of the final garment must be drawn with much thought so that it will appeal to the customer segment it is aimed at. The designer will have to figure out how he/she is going to communicate with the shopper when deciding on the final form of the garment (I 1).

Nevertheless, as expressed by some informants, certain haptic sensations are more desirable than others. For example, Informant 4 stated that smoothness is more desirable than 
roughness. Informant 14 suggested that the use of lightweight materials will increase across many industries.

\section{Consumer haptic perception}

\subsection{Haptic perception}

The interview data supported the assumption that sensation as perceived through touch by the hands, affects consumers' perceptions, ultimately creating a subconscious trigger that influences their impression formation and product judgement. This supports the work of Krishna (2012), who defined haptic perception as the "awareness and interpretation of haptic sensory information". Interview data suggested that information received by touching significantly influences the consumer's product perception, in particular aesthetic appeal, perceived quality, personality perception, perceived comfort, price and confidence, while the perception of touch could even evoke negative feelings (e.g. disgust).

The sensations and movements associated within haptics generally appeared to have a strong bearing on a product's aesthetic appeal to consumers, which is centered on perceptions of beauty and how a product appeals to the senses:

I think our fabrics are very soft and tactile. I am not in favour of rigid materials, because stiff fabrics don't look beautiful against the skin - not to my eyes, anyway. I think it has to do with the way it drapes. Again, I probably don't think I will use them within my brand (I 8).

However, the kind of aesthetics expected by customers from haptics can change over time and across different product types. Reflecting on their design context, Informant 6 explained that although consumers now embrace rough, thick and stiff as a current fashion trend, they would have rejected the same a few years ago. Moreover, haptics influence a consumer's perception of a product's quality. The study supported the four critical dimensions of quality, namely, perceived quality, performance, reliability and durability (Garvin, 1987). "I suppose when something is flimsy, you generally think it is high quality" (I 7). Informant 12 stated that lightweight products are considered less durable compared to heavier weight products.

Another important phenomenon that emerged from the study was the metaphorical association of haptics with the perception of a person's personality:

So, rugged and sleek to me is the classic, handsome Australian man who is considered the archetypal rugged handsome man [...]. Someone like Hugh Jackman who often played rugged characters on screen. Masculine, yes. But then you have someone like George Clooney, who is always sleek. He always plays sleek characters (I 12).

Comfort was recognised as another characteristic. For example, Informants 7, 10 and 14 explained how their clients rely on their sense of touch to evaluate the sense of comfort that a clothing product can provide. For example, Informant 7 stressed that if a garment feels cold to the touch it will not feel comfortable.

Moreover, the study drew attention to the essential role haptic perception plays in influencing a consumer's assessment of value. As demonstrated by some informants, regardless of their knowledge and experience, their perceptions of value were based on the haptic properties of the product. They gained this information by simply touching the products, suggesting that information attained through touch can serve as a crucial driver of price perception. For example, lightness of weight is associated with a cheaper price perception. However, touch can also influence a consumer's negative reaction towards products, particularly if they have been previously touched by another person. This negative outcome of touch is referred to as "disgust" here (a response that is prompted by the suspicion of uncleanliness). Informant 6 explained that some consumers are overly 
sensitive to the presence of suspected impurities in the product when it has been previously handled or worn by another person:

Because as soon as you put your hand on the fabric it starts to have an effect on the fabric, especially in the case of delicate fabrics like silk satin crepe. The very soft satin has an affinity for impurities so it tends to absorb any kind of body oil or any type of makeup. That would instantly stain the garment and by viewing the material from an angle you could see the marks left by the fingertips. This would just drive me crazy because the next time someone tries it on that person would say, 'Oh! It's been touched. It's dirty (I 6).

This finding is consistent with that of previous consumer contamination studies that investigated the role of incidental touch on consumer behaviour, which was that consumers tend to evaluate products previously handled by other shoppers less favourably (Argo et al., 2006).

\subsection{Individual factors}

The influence of individual factors on haptic perception is referred to here as "individual level factors that influence a consumer's haptic experience". The majority of informants explained that people are highly sensitive to tactile stimuli and so they are quite responsive to the sense of touch and feel. Informant 8 stressed, "Tactility is absolutely important, because, again my client is very tactile". This research supported the two types of individual orientation towards touch posited in the touch literature, namely, the goal driven utilitarianoriented touch and the sensory pleasure driven hedonic-oriented touch (De Canio and Fuentes-Blasco, 2021; Peck and Childers, 2003a; Ranaweera et al., 2021).

Data supported the utilitarian orientation of touch. As indicated by informants, our sense of touch provides essential information related to the goal driven evaluative outcomes of a purchase decision that is usually not associated with sensory pleasure. Informant 7 described that touch is the factor that immediately sends a customer back to the shop if he is not satisfied by the haptic information gained through touching. "This happens because you move it. You look at the whole garment, you pick it up, and see how it drapes. So, touch is a factor and it might immediately send you back if you don't like the feel of it" (I 7). Informant 2 stated that if consumers are satisfied with the hand feel they will be willing to put up with other shortcomings - "If something feels nice to the touch, I think people will put up with other things" (I 2).

Interview data also supported the hedonic orientation of touch. Some informants suggested that consumers enjoy the sensation of touching, holding or sometimes squeezing products or materials. For example, Informant 5 admitted that she cannot resist the temptation to touch products whenever she goes shopping. "During much of the time when I am designing and whenever I am out I can't help myself from just touching all the clothes I see" (I 5). Moreover, despite the convenience and ease of online shopping, which is mostly a goal-driven action, consumers still prefer to visit brick and mortar stores to enjoy the sensation of touching and feeling the products. Informant 12 explained, "I have to say that as a consumer I often shop online, but it is rather more fun going into stores and looking and feeling and touching fabrics and clothes" (I 12).

Another phenomenon that became evident during this qualitative exploration was the consumers' preference for uniqueness when acquiring and possessing haptic information. The preference for haptics varied across individuals. For example, Informant 4 explained that even though the majority of their customers liked softness against their skin, there could still be customers whose desire to stand out from the crowd drove them to go in for some strongly contrasting haptic property such as a coarse texture. 


\subsection{External environmental factors}

Another salient thematic topic that emerged from the discussion is the influence of external environmental factors on haptic perception, which this paper refers to as "external environmental factors that influence consumers' haptic experience". Data suggested two major external environmental factors, namely, ambient temperature and technological advancements.

Prior marketing literature posits those physical surroundings and the atmosphere can impact consumer judgement and decision-making (Biswas et al., 2019; Jha et al., 2020; Turley and Milliman, 2000). Consumer psychology studies also show that consumer preferences such as conformity are influenced by ambient temperature (Huang et al., 2014). This study also found that a consumer's haptic perception is influenced by ambient temperature. Informant 7 explained, "I actually think that a lot of this is also impacted by the ambient temperature prevailing in the place where you are shopping. If it is a really cold day, you are naturally going to purchase something warm and cosy". Informants 3, 6, 8, 11, 12 and 14 similarly emphasised that in Queensland, Australia, which has a subtropical climate, the temperature drives consumers to seek lightweight materials that feel cool to the touch.

Technological advancements have changed the world in countless ways. This study revealed some positive influences of technology on a consumer product's touch-based properties, which have a bearing on touch-based information processing:

I come across a lot of innovative fabrics that possess different tactile properties, which appeal to the senses when you touch them, unlike a normal fabric. You can find innovative fabrics of course, from all sources. You can even find thermochromic fabrics that show a reversible change of colour on warming, so that by touching them, you can leave your fingerprints on the surface. Those things are available in the market [. . . ] and there are so many varieties (I 10).

Nevertheless, advanced technology can also lead to negative consequences on consumers' haptic perceptions. For example, Informant 5 explained how technology could be exploited to mimic certain special haptic qualities cheaply, with the result that inexpert consumers would have trouble distinguishing between an original product and a spurious product.

\subsection{Multi-dimensionality of haptics}

The next theme is the multi-dimensionality of haptics, which this research defines as "the integration by the consumer of several haptic inputs rather than focus on a single haptic modality". Psychophysics literature suggests that information obtained through the sense of touch is important for the evaluation of products that vary in terms of four material properties, which are texture, weight, temperature and hardness (Lederman and Klatzky, 1993). This study sheds more light on this by showing that it is quite feasible for people to acquire, store and retrieve different types and amounts of haptic information simultaneously. For example, Informant 1 preferred a soft texture and expected it to be warm at the same time.

The rationale behind this novel haptic notion is explained by drawing insights from original haptic literature rooted in perception and psychophysics, where touch is referred to as an active multi-dimensional sense derived from the integration of different sensory inputs rather than a single sensory modality (Klatzky and Lederman, 2003). This finding also shed some light on Heller and Schiff (2013)'s a discussion on the theoretical issues pertaining to haptic processing, which raises the question "whether we process tactile input in serial form or in parallel"? They assume that this issue indicates the possibility of attending to more than one haptic property at a time. Our findings clearly show that a person's haptic perception of a stimulus or product could be enhanced by the presence of multiple haptic properties simultaneously. This is exemplified by Informant 2 who stressed that we cannot 
SJME

26,1

just isolate one attribute when people are feeling more than one at the same time. Informant 5 explained that "Because you are feeling more than just one property at the same time, you are taking in a fair bit of information". Informant 2 claimed that there are products that are light and warm at the same time. Informant 3 observed a closer relationship between hardness and firmness than softness and flimsiness. Informant 11 said that if a product is soft, you perceive it as being lighter in weight. Informant 10 stressed that some consumers doubt the stability of soft, delicate and flimsy products. Informant 13 described that "When a material is bulky [heavy], it is subconsciously considered as less breathable, so temperature is also represented indirectly".

\subsection{Haptic cue congruity}

Multi-dimensionality of haptics provides further insight on how haptic cues correspond with one another. This study recognises this novel influence as haptic cue congruity. From a sensory marketing perspective, Krishna et al. (2010) define cue congruence to be the degree of fit among different characteristics of a stimulus. In a similar vein, this study defines "the degree of fit among haptic cues" as haptic cue congruence. For example, hard and firm properties have a strong match between their haptic characteristics, thus we recognise them as being haptically congruent. Similarly, materials with matching properties like soft and flimsy, warm and heavy, cool and lightweight and soft and lightweight have the same natural fit within them.

On the other hand, we refer to haptic cue incongruence as the degree of mismatch between haptic cues. For example, smooth and heavy properties have a natural mismatch. Similarly, soft and heavy, lightweight and warm and heavy and cold materials have the same mismatch between their physical characteristics. A recent paper which has examined the influence of haptic attributes on consumer product impressions offers some important empirical evidence to support the notion of haptic cue congruity (Ranaweera et al., 2021). More especially, this research shows that the unexpected incongruity between smooth and heavy haptic cues evoke favourable response towards exciting brands (Table 5 for extracted quotes that support the multi-dimensionality of haptics and haptic cue congruity).

\subsection{Haptic dominance}

The next theme is haptic dominance. There is a large body of evidence on cross-modal interactions among the senses, with respect to sensory dominance (Colavita, 1974; Schifferstein et al., 2010). However, there is no early research evidence to suggest which of the four material properties is the most readily perceptible to our sense of touch (Lederman and Klatzky, 1987). In other words, which of these properties is the most dominant one so that it is noticed first by the consumer before he becomes aware of the other properties? This study posits that our brain may not give equal weightage to the information coming from different haptic modalities. Rather, one modality could dominate others, thereby drawing the greater part of the consumers' attention to that particular sensory property with less attention being paid to the others. This research defines haptic dominance as what occurs when one haptic modality is given greater weightage by a consumer compared to the attention he pays to other haptic modalities. For example, Informant 2 explained, "I definitely think that the feel or texture of a garment is probably more important than some of the other qualities, because that is what makes something feel nice" (I 2).

Interview data suggested that weight is probably the second most important factor. Informant 3 emphasised that weight plays a pivotal role in the product design and development process. 


\begin{tabular}{|c|c|c|c|c|}
\hline Informant & Selected quotes & $\begin{array}{l}\text { The multi- } \\
\text { dimensionality } \\
\text { of haptics }\end{array}$ & $\begin{array}{l}\text { Haptic cue } \\
\text { congruence/ } \\
\text { incongruence }\end{array}$ & $\begin{array}{r}\text { Consumer } \\
\text { haptic } \\
\text { perception }\end{array}$ \\
\hline 1 & $\begin{array}{l}\text { "Yes, absolutely; and I would say rather than hard, it might } \\
\text { be the firmness of the weave. How firm it is and how } \\
\text { malleable and flexible it is" }\end{array}$ & $\begin{array}{l}\text { Firm }+ \\
\text { malleable }+ \\
\text { flexible }\end{array}$ & $\begin{array}{l}\text { Haptic cue } \\
\text { incongruence }\end{array}$ & \\
\hline 1 & $\begin{array}{l}\text { "If it is a very stiff, firm fabric, then we could call it a hard } \\
\text { fabric" }\end{array}$ & $\begin{array}{l}\text { Stiff }+ \text { firm }+ \\
\text { hard }\end{array}$ & $\begin{array}{l}\text { Haptic cue } \\
\text { congruence }\end{array}$ & \\
\hline 2 & $\begin{array}{l}\text { "Material is like } 100 \% \text { linen and it is thick as well. It is } \\
\text { quite cool to the touch" }\end{array}$ & Thick + cool & $\begin{array}{l}\text { Haptic cue } \\
\text { incongruence }\end{array}$ & \\
\hline 4 & $\begin{array}{l}\text { "I guess they are all related in some way. People generally } \\
\text { relate heaviness to temperature... If it's something that's } \\
\text { quite heavy, they feel a bit hot" }\end{array}$ & Heavy + hot & $\begin{array}{l}\text { Haptic cue } \\
\text { congruence }\end{array}$ & \\
\hline 6 & $\begin{array}{l}\text { "Crisp is the word you would use to describe a certain type } \\
\text { of silk. Silk Taffeta. This material is quite crisp and } \\
\text { crunchy, and therefore, hard" }\end{array}$ & $\begin{array}{l}\text { Crisp }+ \\
\text { crunchy }+ \\
\text { hard }\end{array}$ & $\begin{array}{l}\text { Haptic cue } \\
\text { congruence }\end{array}$ & \\
\hline 7 & "Material is probably fluffy and smooth again" & $\begin{array}{l}\text { Fluffy + } \\
\text { smooth }\end{array}$ & $\begin{array}{l}\text { Haptic cue } \\
\text { congruence }\end{array}$ & \\
\hline 8 & $\begin{array}{l}\text { "We also use cotton organdie, which I would call hard. But } \\
\text { at the same time, it is cool because it's pure cotton" }\end{array}$ & Hard + cool & $\begin{array}{l}\text { Haptic cue } \\
\text { incongruence }\end{array}$ & $\begin{array}{l}\text { Table } 5 . \\
\text { The multi- }\end{array}$ \\
\hline 12 & $\begin{array}{l}\text { "Hard-Soft feel is really about texture, so again you can } \\
\text { probably throw some other words in there, like hard } \\
\text { fabrics are usually also stiff as well" }\end{array}$ & Hard + stiff & $\begin{array}{l}\text { Haptic cue } \\
\text { congruence }\end{array}$ & $\begin{array}{r}\text { dimensionality of } \\
\text { haptics and haptic } \\
\text { cue congruity }\end{array}$ \\
\hline
\end{tabular}

Informant 4 stated that when she touches something, she would immediately go for texture and then the weight of the product. "These are the two main qualities that I would straightaway go for" she said. Some informants suggested that thermal sensation could also play a role when people touch products, they plan on buying. However, there could also be some negative consequences of temperature as far as haptic perception is considered. As Informant 10 claimed, when consumers come into the store and happen to feel a hot [warm] vibe upon touching a product, they seem to lose interest in buying that item. "When they come into the store, touch the product and find it gives that hot vibe, they are not interested in buying it" (I 10).

Hardness was the least prominent aspect in the data. Informant 4 emphasised that hardness is only one particular aspect and suggested that weight somehow has a greater haptic impact than hardness.

\section{Discussion and conclusion}

This research provides a more comprehensive understanding of haptics as a key driver of consumers' motivation to buy a product after they have touched and handled it. This research proposes a conceptual model of consumer haptic perception that integrates the following seven haptic influences, namely, the effects of haptic sensation, haptic perception, the influence of individual factors, the influence of external environmental factors, the multi-dimensionality of haptics, haptic cue congruity and haptic dominance.

This study identifies the sensations that result from touching and feeling haptic information as "haptic sensation". More specifically, the findings reveal that the sensation felt by a consumer creates a powerful emotional connection between him and the product. The findings suggest that the haptic sensation felt by touching with the hands ultimately affects the consumers' perception, and subsequently creates a subconscious impression that 
informs the consumers' product judgement. In particular, the consumers' assessment of the product will be based on such factors as aesthetic appeal, perceived quality, personality perception, perceived comfort, perceived price, perceived confidence and possibly a negative perception of touch (disgust). This is consistent with the view that sensation and perception are stages of processing by the senses, which will affect consumers' perception, judgement and behaviour (Krishna et al., 2016).

This study also observes consumers' preference for uniqueness when acquiring and possessing touch-based information. More specifically, this research shows the influence of individual factors on a consumer's haptic perception. In particular, the findings support the two types of individual orientations of touch, namely, the goal driven utilitarian-oriented touch and the sensory pleasure driven hedonic-oriented touch (De Canio and Fuentes-Blasco, 2021; Peck and Childers, 2003a; Ranaweera et al., 2021). This research next draws attention to two environmental factors that can influence a consumer's haptic perception, namely, ambient temperature and technological advancements.

While the current understanding of the embodiment effects with respect to touch are specific to haptic information corresponding to a single material property, this research stresses the importance of embracing the integrative nature of haptics that includes all four material properties, namely, texture, weight, temperature and hardness. This theme was referred as the multi-dimensionality of haptics. For example, a product's smooth texture and light weight could simultaneously drive consumers' haptic perception. Grounded on this, the research further conceptualises that haptic cues may complement each other in multi-faceted ways, thereby giving rise to two other novel haptic concepts, namely, haptic-cue congruence and haptic cue incongruence. For instance, smoothness and lightness have a natural fit. In contrast, smoothness and heaviness or roughness and lightness have a natural mismatch. Finally, the notion of haptic dominance was discussed.

Despite the large body of evidence on sensory dominance, specifically the higher receptivity to vision over other senses, no prior empirical work has discussed if any of the four material properties of texture, weight, hardness and temperature could dominate another property or exert any influence over it. This research shows that the dominance of certain haptic properties, in particular the texture of a product, exerts greater influence in drawing a consumer's attention compared to other haptic modalities.

\subsection{Theoretical implications}

This exploratory investigation adds to the evolving body of literature on sensory touch by illustrating the dynamic nature of haptics. This is the first study in marketing to propose a conceptual model comprising several new haptic influences, especially the multi-dimensionality of haptics, haptic cue congruity and haptic dominance. This will provide new insights to future sensory marketing researchers so they may examine the impact of touch on consumer judgement and decision-making. Broadly, this understanding provides insights into theory building in other types of sensory research as well, such as in exploring multi-dimensionality among other sensory modalities. Further, this research took the first step in designing a realistic and workable protocol for future sensory marketing studies by determining semantic scales to measure consumers' haptic perception. Specifically, a consumer could place a mark on one of the lines to indicate the point along the continuum that characterises his or her evaluation of the stimulus. For example, if someone perceived a product's weight as very light, they can select the line closest to that adjective. 


\subsection{Practical implications}

This research offers some important implications to marketing practitioners. The study provides a rich understanding of why marketers must exploit consumers' receptivity to touch sensation and perception by attracting consumers through various forms of haptic interactions. Particularly, the research suggests firms to consider the cue congruity effect among products. For example, practitioners could create their products by combining incongruent haptic cues, for instance, applying an extra smooth finish on a heavy metallic base. In contrast, they could develop products by permitting haptic cues to be congruent, such as using smooth and also lightweight materials. This research further shows the notion of haptic dominance, thereby suggests practitioners that although all four haptic properties are open to obtain information during consumers' product-interactions, some haptic properties can have a larger effect on the product experience than others. For example, hardness may play a more pivotal role than texture in the context of interior design or consumer electronics.

Further, this research provides some insights on market segmentation by taking into account individual differences in processing haptic information. This research also shows the impact of environmental factors on consumers' haptic perception and consequential decision-making. Moreover, this research illustrates that certain products are more suitable for touch evaluation. Therefore, practitioners could determine more easily which products could benefit through incorporating special haptic properties to appeal to consumers (Table 6 for main conclusions and the main theoretical and managerial implications of this research).

\subsection{Limitations and future research directions}

Given that this study is among the first to explore the nature of haptics, it is subject to a few limitations, which are likely to offer some scope for further research. The main limitation of this study is the small sample size of informants. Further, the selected fashion industry experts were a reliable source of information, their interpretation on haptic perception might not be as same as regular consumers. To address these, limitations, future research is recommended to validate the preliminary findings of this study by adopting a quantitative research approach that uses a larger sample of consumers. Future research could also examine haptic effects among different market

\begin{tabular}{|c|c|}
\hline Conclusion & Theoretical and managerial implications \\
\hline $\begin{array}{l}\text { A conceptual model of consumer haptic } \\
\text { perception consisting of seven key } \\
\text { influences: the effects of haptic } \\
\text { sensation, haptic perception, the } \\
\text { influence of individual factors, the } \\
\text { influence of external environmental } \\
\text { factors, the multi-dimensionality of } \\
\text { haptics, haptic cue congruity and } \\
\text { haptic dominance }\end{array}$ & $\begin{array}{l}\text { - Haptic sensation felt by touching with the hands ultimately } \\
\text { affects the consumers' perception, and subsequently creates a } \\
\text { subconscious impression that informs the consumers' product } \\
\text { judgement } \\
\text { - Individual and environmental factors impact consumers' haptic } \\
\text { perception and consequential decision-making } \\
\text { - Consumers acquire, store and retrieve different types and } \\
\text { amounts of haptic information simultaneously } \\
\text { - Haptic cues complement each other in multi-faceted ways } \\
\text { (haptic cue congruity) } \\
\text { - The dominance of certain haptic properties, in particular the texture } \\
\text { of a product, exerts greater influence in drawing a consumer's } \\
\text { attention compared to other haptic modalities }\end{array}$ \\
\hline
\end{tabular}



findings of this research could be built upon by follow up studies that would include the development of a haptic scale to measure the haptic perception of products. Furthermore, replication studies are necessary to examine the notion of haptic dominance. For example, texture could be the dominant haptic cue because of the fashion and texture context in which it emerged. Further, haptic dominance could be further expanded in the future with some quantitive exploration, such as conjoint analysis.

As it was beyond the scope of the current research, future research is recommended to validate some of the preliminary findings through a different data collection process. For example, a follow-up survey could measure the effect of haptic interactions on other marketing constructs such as consumer's impulsive purchasing behaviour. This research further suggests future research to capture haptic effects across different product categories such as high involvement (e.g. consumer electronic products) or low involvement products (e.g. grocery products).

\section{References}

Argo, J.J., Dahl, D.W. and Morales, A.C. (2006), "Consumer contamination: how consumers react to products touched by others", Journal of Marketing, Vol. 70 No. 2, pp. 81-94.

Babbie, E.R. (2017), The Basics of Social Research, Cengage Learning. Boston.

Batra, R., Seifert, C. and Brei, D. (2016), The Psychology of Design: Creating Consumer Appeal, Routledge.

Biswas, D., Lund, K. and Szocs, C. (2019), "Sounds like a healthy retail atmospheric strategy: effects of ambient music and background noise on food sales", Journal of the Academy of Marketing Science, Vol. 47 No. 1, pp. 37-55.

Bogner, A., Littig, B. and Menz, W. (2009), Introduction: Expert Interviews - an Introduction to a New Methodological Debate, Palgrave Macmillan UK, London.

Citrin, A.V., Stem, D.E., Spangenberg, E.R. and Clark, M.J. (2003), "Consumer need for tactile input", Journal of Business Research, Vol. 56 No. 11, pp. 915-922.

Colavita, F.B. (1974), "Human sensory dominance".

Creswell, J.W. (2003), Research Design: qualitative, Quantitative, and Mixed Method Approaches, Sage Publications, Thousand Oaks, CA.

De Canio, F. and Fuentes-Blasco, M. (2021), "I need to touch it to buy it! How haptic information influences consumer shopping behavior across channels", Journal of Retailing and Consumer Services, Vol. 61, p. 102569.

Flavián, C., Gurrea, R. and Orús, C. (2017), "The influence of online product presentation videos on persuasion and purchase channel preference: the role of imagery fluency and need for touch", Telematics and Informatics, Vol. 34 No. 8, pp. 1544-1556.

Gallace, A. and Spence, C. (2011), "Tactile aesthetics: towards a definition of its characteristics and neural correlates", Social Semiotics, Vol. 21 No. 4, pp. 569-589.

Garvin, D. (1987), “Competing on the eight dimensions of quality”, Harvard Business Review [Online], p. 65.

Gibson, J.J. (1966), "The senses considered as perceptual systems”, Houghton Mifflin, Oxford, England.

Gioia, D.A., Corley, K.G. and Hamilton, A.L. (2013), "Seeking qualitative rigor in inductive research:Notes on the gioia methodology", Organizational Research Methods, Vol. 16 No. 1, pp. 15-31.

Grohmann, B., Spangenberg, E.R. and Sprott, D.E. (2007), "The influence of tactile input on the evaluation of retail product offerings", Journal of Retailing, Vol. 83 No. 2, pp. 237-245. 
Heller, M.A. (1989), “Texture perception in sighted and blind observers”, Perception and Psychophysics, Vol. 45 No. 1, pp. 49-54.

Heller, M.A. and Schiff, W. (2013), The Psychology of Touch, Routledge.

Hennink, M., Hutter, I. and Bailey, A. (2020), Qualitative Research Methods, Sage.

Consumer haptic perception

Huang, X., Zhang, M., Hui, M.K. and Wyer, R.S. (2014), "Warmth and conformity: the effects of ambient temperature on product preferences and financial decisions", Journal of Consumer Psychology, Vol. 24 No. 2, pp. 241-250.

Hultén, B. (2015), Sensory Marketing, Theoretical and Empirical Grounds, Routledge, Taylor and Francis.

Jha, S., Balaji, M.S., Peck, J., Oakley, J. and Deitz, G.D. (2020), "The effects of environmental haptic cues on consumer perceptions of retailer warmth and competence", Journal of Retailing, Vol. 96 No. 4.

Katz, D. and Krueger, L.E. (1989), The World of Touch, L. Erlbaum.

Kerr, C., Nixon, A. and Wild, D. (2010), "Assessing and demonstrating data saturation in qualitative inquiry supporting patient-reported outcomes research", Expert Review of Pharmacoeconomics and Outcomes Research, Vol. 10 No. 3, pp. 269-281.

Klatzky, R.L. and Lederman, S.J. (1992), "Stages of manual exploration in haptic object identification", Perception and Psychophysics, Vol. 52 No. 6, pp. 661-670.

Klatzky, R.L. and Lederman, S.J. (1993), "Toward a computational model of constraint-driven exploration and haptic object identification", Perception, Vol. 22 No. 5, pp. 597-621.

Klatzky, R.L. and Lederman, S.J. (2003), Touch, John Wiley and Sons, Inc.

Klatzky, R.L., Lederman, S.J. and Matula, D.E. (1993), "Haptic exploration in the presence of vision", Journal of Experimental Psychology: Human Perception and Performance, Vol. 19, pp. 726-743.

Klatzky, R.L., Lederman, S.J. and Reed, C. (1987), "There's more to touch than meets the eye: the salience of object attributes for haptics with and without vision", Journal of Experimental Psychology: General, Vol. 116 No. 4, pp. 356-369.

Klatzky, R.L., Lederman, S.J. and Metzger, V.A. (1985), "Identifying objects by touch: an 'expert system”, Perception and Psychophysics, Vol. 37 No. 4, pp. 299-302.

Klatzky, R.L. and Peck, J. (2012), "Please touch: Object properties that invite touch", IEEE Transactions on Haptics, Vol. 5 No. 2, pp. 139-147.

Krishna, A. (2010), Sensory Marketing: research on the Sensuality of Products, Routledge, New York, NY.

Krishna, A. (2012), "An integrative review of sensory marketing: engaging the senses to affect perception, judgment and behavior", Journal of Consumer Psychology, Vol. 22 No. 3, pp. 332-351.

Krishna, A., Cian, L. and Aydınoğlu, N.Z. (2017), "Sensory aspects of package design", Journal of Retailing, Vol. 93 No. 1, pp. 43-54.

Krishna, A., Cian, L. and Sokolova, T. (2016), “The power of sensory marketing in advertising”, Current Opinion in Psychology, Vol. 10, pp. 142-147.

Krishna, A., Elder, R.S. and Caldara, C. (2010), "Feminine to smell but masculine to touch? Multisensory congruence and its effect on the aesthetic experience", Journal of Consumer Psychology, Vol. 20 No. 4, pp. 410-418.

Krishna, A. and Morrin, M. (2008), "Does touch affect taste? The perceptual transfer of product container haptic cues", Journal of Consumer Research, Vol. 34 No. 6, pp. 807-818.

Krishna, A. and Schwarz, N. (2014), "Sensory marketing, embodiment, and grounded cognition: a review and introduction", Journal of Consumer Psychology, Vol. 24 No. 2, pp. 159-168.

Kühn, F., Lichters, M. and Krey, N. (2020), "The touchy issue of produce: need for touch in online grocery retailing", Journal of Business Research, Vol. 117, pp. 244-255. 
SJME

26,1

Lederman, S.J. and Klatzky, R.L. (1987), "Hand movements: a window into haptic object recognition", Cognitive Psychology, Vol. 19 No. 3, pp. 342-368.

Lederman, S.J. and Klatzky, R.L. (1993), "Extracting object properties through haptic exploration”, Acta Psychologica, Vol. 84 No. 1, pp. 29-40.

Lederman, S.J. and Klatzky, R.L. (2009), "Haptic perception: a tutorial", Atten Percept Psychophys, Vol. 71 No. 7, pp. 1439-1459.

Littel, S. and Orth, U.R. (2013), "Effects of package visuals and haptics on brand evaluations", European Journal of Marketing, Vol. 47 Nos 1/2, pp. 198-217.

Nolan, C.T. and Garavan, T.N. (2016), "Human resource development in SMEs: a systematic review of the literature", International Journal of Management Reviews, Vol. 18 No. 1, pp. 85-107.

Orth, U.R. and Malkewitz, K. (2008), "Holistic package design and consumer brand impressions", Journal of Marketing, Vol. 72 No. 3, pp. 64-81.

Peck, J. and Childers, T.L. (2003a), "Individual differences in haptic information processing: the "need for touch' scale”, Journal of Consumer Research, Vol. 30 No. 3, pp. 430-442.

Peck, J. and Childers, T.L. (2003b), "To have and to hold: the influence of haptic information on product judgments", Journal of Marketing, Vol. 67 No. 2, pp. 35-48.

Peck, J. and Childers, T.L. (2006), "If I touch it I have to have it: individual and environmental influences on impulse purchasing", Journal of Business Research, Vol. 59 No. 6, pp. 765-769.

Peck, J. and Johnson, J.W. (2011), "Autotelic need for touch, haptics, and persuasion: the role of involvement”, Psychology and Marketing, Vol. 28 No. 3, pp. 222-239.

Peck, J. and Wiggins, J. (2006), "It just feels good: customers' affective response to touch and its influence on persuasion”, Journal of Marketing, Vol. 70, pp. 56-69.

Peck, J. (1999), "Extraction of haptic properties: individual characteristics and stimulus characteristics", Doctor of Philosophy University of Minnesota.

Pino, G., Amatulli, C., Nataraajan, R., De Angelis, M., Peluso, A.M. and Guido, G. (2020), "Product touch in the real and digital world: how do consumers react?", Journal of Business Research, Vol. 112, pp. 492-501.

Piqueras-Fiszman, B. and Spence, C. (2012), "The weight of the container influences expected satiety, perceived density, and subsequent expected fullness", Appetite, Vol. 58 No. 2, pp. 559-662.

Ranaweera, A.T., Martin, B. A S. and Jin, H.S. (2021), "What you touch, touches you: the influence of haptic attributes on consumer product impressions", Psychology and Marketing, Vol. 38 No. 1, pp. 183-195.

Ringler, C., Sirianni, N.J., Gustafsson, A. and Peck, J. (2019), "Look but don't touch! The impact of active interpersonal haptic blocking on compensatory touch and purchase behavior", Journal of Retailing, Vol. 95 No. 4.

Saldaña, J. (2015), “The coding manual for qualitative researchers”, Sage, London.

Saunders, B., Sim, J., Kingstone, T., Baker, S., Waterfield, J., Bartlam, B., Burroughs, H. and Jinks, C. (2018), "Saturation in qualitative research: exploring its conceptualization and operationalization", Quality and Quantity, Vol. 52 No. 4, pp. 1893-1907.

Schifferstein, H.N.J., Otten, J.J., Thoolen, F. and Hekkert, P. (2010), "The experimental assessment of sensory dominance in a product development context", J. of Design Research, Vol. 8 No. 2, pp. 119-144.

Shadish, W.R., Cook, T.D. and Campbell, D.T. (2002), Experimental and Quasi-Experimental Designs for Generalized Causal Inference, Mifflin and Company, Houghton.

Solomon, M.R. (2013), Consumer Behaviour: Buying, Having, Being, (3rd ed., Australian ed.), Frenchs Forest, Pearson Australia, NSW.

Turley, L.W. and Milliman, R.E. (2000), "Atmospheric effects on shopping behavior: a review of the experimental evidence”, Journal of Business Research, Vol. 49 No. 2, pp. 193-211. 
Velasco, C. and Spence, C. (2019), Multisensory Packaging: designing New Product Experiences, Springer.

Webb, A. and Peck, J. (2015), "Individual differences in interpersonal touch: on the development, validation, and use of the 'comfort with interpersonal touch' (CIT) scale", Journal of Consumer Psychology, Vol. 25 No. 1, pp. 60-77.

Consumer

haptic perception

Wilson, M. (2002), "Six views of embodied cognition", Psychonomic Bulletin and Review, Vol. 9 No. 4, pp. 625-636.

Wu, B., Klatzky, R.L. and Hollis, R.L. (2011), "Force, torque and stiffness: interactions in perceptual discrimination", IEEE Trans Haptics, p. 1.

\section{Corresponding author}

Achini Tharaka Ranaweera can be contacted at: achinir@uom.lk

For instructions on how to order reprints of this article, please visit our website: www.emeraldgrouppublishing.com/licensing/reprints.htm Or contact us for further details: permissions@emeraldinsight.com 